UDC $631 ; 336.2$

\title{
TAX STIMULATION OF AGRICULTURAL GOODS MANUFACTURERS
}

Article info

Received

30.04.2020

Accepted

24.06.2020

Postgraduate of Uman National University of Horticulture 1, Institute Str., Uman, 20305, Ukraine

E-mail: petro19500807@ gmail.com; sergejkolotuha@ gmail.com; chekalyksvttt@ gmail.com

\section{P. Bechko, S. Kolotukha, S. Ptashnyk, Ju. Nahorna}

Bechko, P., Kolotukha, S., Ptashnyk, S., Nahorna, Ju. (2020). Tax stimulation of agricultural goods manufacturers. Scientific Horizons, 06 (91), 60-67. doi: 10.33249/2663-2144-2020-91-6-60-67.

The article defines the purpose of tax stimulation of agricultural enterprises, namely the economic impact of the state on the production, processing and sale of agricultural products, raw materials and food, as well as logistics aimed at improving the efficiency of activities at all levels and harmonizing the interests of the state and enterprises. A social survey was conducted to evaluate the tax system of Ukraine and the results were presented. The system of tax stimulation of agricultural entities is presented. It is proved that innovation and investment policy has a significant impact on the activities that at this stage of financial and economic development tax regulation of agricultural entities does not fully contribute to the development and growth of production, their functioning on self-financing and self-sufficiency. The agrarian sector of the economy is strategically important, which is why state support of the national agrarian sector is aimed at its effective functioning, which can be achieved through prudent state regulation in general and methods of tax stimulation in particular. Therefore, taxation, which has undergone significant changes in recent years, has become one of the key methods of state regulation. At the same time, as practice shows, the introduction of these changes is not always adapted to the tendencies of transformation of tax systems in the agrarian sphere in the countries with developed market relations. The state must guarantee the stability of the basic principles of taxation, and the mechanisms and rules of their action must be set out in a single document - the Tax Code of Ukraine. This document should embody the essence of a new or updated tax policy that will not only determine the trajectory of tax relations and tax law development, but will combine tax reform trends and trends with the country's economic development strategy. The conducted research shows that at this stage of financial and economic development, tax regulation of agricultural business entities does not fully contribute to the development and growth of production, their functioning on self-financing and self-sufficiency.

Key words: farms, taxes, regulation, economic development, innovation and investment.

\section{ПОДАТКОВЕ СТИМУЛЮВАННЯ СІЛЬСЬКОГОСПОДАРСЬКИХ ТОВАРОВИРОБНИКІВ}

\section{П. К. Бечко, С. М. Колотуха, С. А. Пташник, Ю. І. Нагорна \\ Уманський національний університет садівництва вул. Інститутська, 1, м. Умань, 20305, Україна}

Сільськогосподарське виробництво відіграє особливу роль у кожній краӥні, оскільки цчей сегмент є основою продовольчої безпеки і одним із найперспективніших напрямів у вирішенні проблеми подолання безробіття. Саме з ичих міркувань держава повинна виходити, формуючи регуляторний механізм для фермерів, особливо у виборі інструментів стимулювання податкового стимулювання. Визначено мету

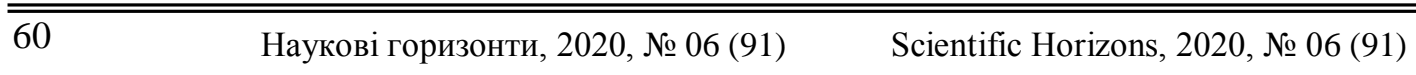


податкового стимулювання суб’єктів господарювання аграрної галузі, а саме економічний вплив держави на виробництво, переробку $i$ реалізацію сільськогосподарської продукиії, сировини $i$ продовольства, а також матеріально-технічне забезпечення, спрямоване на підвищення ефективності діяльності на всіх рівнях $i$ погодження інтересів держсави $і$ підприємств. Проведено соиіальне опитування оиінки податкової системи України з метою детального розгляду системи податкового стимулювання суб'єктів господарювання аграрної галузі. Представлено систему податкового стимулювання суб'єктів господарювання аграрної галузі. Доведено, шзо інноваційно-інвестииійна політика здійснює значний вплив на діяльність сільськогосподарських товаровиробників. Проведене дослідження свідчить, що на даному етапі фінансово-економічного розвитку податкове регулювання суб'єктів господарювання аграрної галузі не повною мірою сприяє розвитку та росту виробництва, функціонування їх на самофінансуванні $i$ самоокупності. Гармонійне поєднання иих складових податкових стимулів механізму державного регулювання на основі пріоритетів сприяє сталому розвитку иього сектора економіки, високому рівню ефективності податкової системи та оптимальному податковому навантаженню, що стимулює виробничу діяльність підприємств, яке стане перспективним напрямом подальших досліджень.

Ключові слова: сільськогосподарські підприємства, податки, державне регулювання, економічний розвиток, стимулювання, інновації, інвестииіï.

\section{Вступ}

Сільськогосподарський сектор економіки має стратегічне значення, тому державна підтримка національного аграрного сектору спрямована на його ефективне функціонування, що може бути досягнуто за рахунок збалансованого державного регулювання в цілому та, зокрема, методів податкового стимулювання. Тому оподаткування, яке зазнало значних змін за останні роки, стало одним із ключових методів державного регулювання. У той же час, як показує практика, реалізація цих змін не завжди адаптована до тенденцій трансформації податкових систем у аграрному секторі країн 3 розвиненими ринковими відносинами.

Питання впливу держави на розвиток сільського господарства податковими методами та інструментами висвітлюються у працях багатьох науковців та практиків. Зокрема, вивчаючи систему податкового регулювання розвитку агросфери України, зазначається, що: «Проблема ефективного регулювання економічних відносин вимагає запропонувати гнучку податкову частину, яка допоможе отримати найкращі результати, які використовуються із застосуванням усіх можливих платників податків. Дуже важливо реконструювати системи підтримки України, створивши реальні технологія переходу агросфери до сучасної моделі, яка розробляється на макроекономічному балансі, складова можливо, необхідна здатність планувати та оптимізувати макроструктурні пропорції» ( $\mathrm{Hudz}$, 2012). Науковцями акцентується увага на податкових пільгах щодо виробництва екологічно чистої сільськогосподарської продукції: «... необхідно запровадити низку заходів у податковій системі для податкових пільг щодо виробництва та реалізації екологічно чистої сільськогосподарської продукції. Тому що витрати, які $\epsilon$ і будуть нести виробники такої продукції, є значними. ... Податкові стимули для виробництва екологічно чистих продуктів... можуть бути досягнуті за рахунок податку на прибуток підприємств та податку на додану вартість» (Dema, 2016).

\section{Матеріали та методи}

Основною метою податкового стимулювання суб'єктів господарювання аграрної галузі $\epsilon$ економічний вплив держави на виробництво, переробку i реалізацію сільськогосподарської продукції, сировини і продовольства, а також матеріально-технічне забезпечення, спрямоване на підвищення ефективності діяльності на всіх рівнях i погодження інтересів держави i підприємств.

В дослідженні використані такі методи, як опитування, описовий, порівняльний аналіз. Згідно 3 опитуванням, лише $18 \%$ експертів оцінили процес підготовки податкової звітності та адміністрування податків позитивно, $33 \%$ вважають процедуру обтяжливою (Kotenko, 2019). За допомогою описового методу було детально розглянуто i описано систему податкового стимулювання суб'єктів господарювання аграрної галузі. В результаті було запропоновано комплекс заходів з розвитку 
P. Bechko, S. Kolotukha, S. Ptashnyk, Ju. Nahorna

податкового стимулювання через діяльності суб'єктів господарювання аграрної галузі.

\section{Результати досліджень та обговорення}

Сільське господарство є особливою галуззю, результатами діяльності якої користується більшість галузей національної економіки. Визначаючи роль податків у національній економіці, слід відмітити, що податкова політика держави щодо аграрної галузі повинна враховувати специфічні особливості сільського господарства, пов'язані 3 диференціальною рентою, ефективністю додаткових вкладень, загальними сприятливими умовами виробництва. За допомогою системи оподаткування держава впливає на обсяг фінансових ресурсів, які залишаються в розпорядженні підприємств. Дослідження особливостей сільськогосподарської галузі $є$ найважливішою передумовою для виявлення закономірностей i умов, які визначають характер оподаткування суб'єктів господарювання, оскільки від галузевої специфіки залежить правильність вирішення поставлених завдань i вибору методів їх оподаткування і податкового регулювання.

Шведський економіст Ерік Ліндаль у роботі «Справедливість оподаткування» запропонував принцип, згідно 3 яким частка індивіда у фінансуванні суспільного блага (інтерпретована як «податкова ціна» граничної одиниці суспільного блага) повинна точно відповідати граничній вигоді суспільного блага для цього індивіда. У його моделі «добровільного обміну» рівновага досягається за умови, коли і ставка податку, й обсяг частини суспільного блага стають об' єктом переговорів ( $H u d z, 2012)$.

3 набуттям незалежності Україна самостійно вибудовувала податкову систему щодо всіх платників податків i зборів у цілому i для сільськогосподарських товаровиробників зокрема. Використання податкової системи для стимулювання аграрного виробництва 3 переходом на ринкові умови господарювання пройшло декілька етапів. Перший етап - період 1991-1995 рр. Характерним для цього періоду є те, що незалежна Україна отримала в спадок високий науковий потенціал, який займав за класифікацією ЮНЕСКО сьоме місце в світі. Науковий потенціал України об'єднував Національну академію наук, численні галузеві науково-дослідні установи, вищі навчальні заклади. Другий етап - період 1996-2003 рр.

Дослідження напрямів податкового
стимулювання сільськогосподарської діяльності потребує врахування значення аграрної галузі для національної економіки України, оскільки впродовж останніх років частка сільського господарства у загальній валовій доданій вартості (ВДВ) постійно зростає. Характерним цього періоду $\epsilon$ позитивні зрушення щодо стимулювання наукового пошуку в Україні, здійснення заходів щодо формування нової національної наукової політики та науковотехнологічної політики на державному, галузевому й регіональному рівнях. Третій етап період 2004-2013 рр., характеризується перебудовою національної науки та освіти за новими стандартами. 3 огляду на це, податкова політика багатогранна, є одним із напрямів економічної політики держави. В той же час, Свропейська бізнес- асоціація погіршила оцінку податкової системи України, про що свідчать результати загального Податкового індексу, який в 2019 р. знизився до 2,90 бала проти 2,98 бала в попередньому періоді $з$ посиланням на результати дослідження, проведеного шляхом опитування 105 експертів 3 компаній-членів асоціації (табл. 1).

Відповідно до проведеного опитування в 2019 р. $26 \%$ з числа опитаних незадоволені податковим законодавством, тоді як в 2018 р. таких було $23 \%$. Крім того, дещо зменшилася кількість респондентів, які ствердно відповіли на питання, чи сприяв чинний податковий режим ведення їх бізнесу. В 2019 р. їх кількість становила $64 \%$, або на 4 відсоткових пункти менше порівняно з 2018 p.

За даними опитування, лише $18 \%$ експертів позитивно оцінили процес підготовки податкової звітності та адміністрування податків, $33 \%$ вважають процедуру громіздкою (Kotenko, 2019).

Зокрема, експерти вказали на основні фактори, які негативно впливають на підготовку податкової звітності та управління, включаючи наступне: кількість часу, витраченого на підготовку податкової звітності та сплату податків; неоднозначність правил та пояснень щодо оподаткування фізичних осіб та платежів; недосконалість системи електронної звітності; поспішне виконання нових правил та відсутність часу на їх адаптацію; кількість платежів. У цей період $28 \%$ респондентів зазнали значних проявів фіскального тиску, що практично повторює результат попереднього періоду (Kotenko, 2019). 
P. Bechko, S. Kolotukha, S. Ptashnyk, Ju. Nahorna

Таблиия 1. Результати соціального опитування оцінки податкової системи України, 2018-2019 рр.

\begin{tabular}{|l|c|c|}
\hline \multicolumn{1}{|c|}{ Показник } & $\mathbf{2 0 1 8} \mathbf{~ p . ~}$ & $\mathbf{2 0 1 9} \mathbf{p .}$ \\
\hline Загальний податковий індекс & 2,98 & 2,90 \\
\hline $\begin{array}{l}\text { Кількість суб'єктів господарювання, що задоволені податковим } \\
\text { законодавством, \% }\end{array}$ & 23,00 & 26,00 \\
\hline Вплив податкової системи на прозорість ведення бізнесу, \% & 68,00 & 64,00 \\
\hline $\begin{array}{l}\text { Позитивний вплив податкової системи на процес підготовки податкової } \\
\text { звітності та адміністрування податків, \% }\end{array}$ & 21,00 & 18,00 \\
\hline $\begin{array}{l}\text { Обтяжливий вплив податкової системи на процес підготовки податкової } \\
\text { звітності та адміністрування податків, \% }\end{array}$ & 26,00 & 33,00 \\
\hline Задовільна якість податкового законодавства України & 64,00 & 59,00 \\
\hline Показники сприяння чинного податкового режиму ведення бізнесу, \% & 68,00 & 64,00 \\
\hline Фіскальний тиск на ведення бізнесу, \% & 28,00 & 28,00 \\
\hline Відсутність фіскального тиску на ведення бізнесу, \% & 18,00 & 29,00 \\
\hline Кількість незадоволених якістю податкових сервісів, \% & 24,00 & 29,00 \\
\hline
\end{tabular}

Тоді як $29 \%$ розуміють, що тиск майже відсутній, і це $9 \%$ експертів, які не стикалися 3 результатами досліджуваних періодів. Відповідно до результатів опису, середні методи, які не стосуються Вашого бізнесу, полягають у наступному: необгрунтовані інформаційні записи та тлумачення правових даних, що містяться в органах влади, та неприйняття контрастних послуг / пояснень; попереднє рішення фіскальних органів; технічні проблеми робочого сервера 3 поданням електронних звітів та секретності в регіонах 3 низькими ставками ПДВ. Крім того, результати опитування показали, що кількість незадоволених якостей в останніх товарах послуг до $29 \%$, порівняно з $24 \%$ у попередні періоди (Kotenko, 2019).

Податкове стимулювання сільськогосподарського виробництва за допомогою податкових інструментів в своїй основі:

- сприяє широкому колу дії, охоплюючи всіх суб'єктів господарювання аграрної галузі, забезпечуючи необхідний рівень виробництва та реалізації продукції, забезпечуючи продовольчу безпеку країни;

- не спотворює конкуренцію, оскільки не є безпосередньою підтримкою конкретних господарюючого суб'єкта;

- знижує рівень залежності від перебігу бюджетного процесу та прихованого лобіювання вибору конкретного проєкту;

- оптимізує витрати суб'єктів діяльності, стимулюючи їх до ризику щодо запровадження нових прогресивних технологій виробництва, економії матеріальних та трудових ресурсів, економії енергоресурсів;

- створює диференційовані стимули для суб'єктів діяльності (застосовуючи різний набір податкових стимулів) залежно від встановлених державою пріоритетів.

3 набранням чинності Податкового кодексу України змінилася філософія оподаткування суб'єктів національної економіки в цілому i сільськогосподарських товаровиробників зокрема. Із загостренням світової фінансової кризи пріоритетним завданням суб'єктів господарювання галузі $\epsilon$ нарощування сільськогосподарської продукції, створення умов на аграрному ринку, забезпечення продовольчої безпеки країни. 3 переходом від фіскальної до сервісної функції системи оподаткування гостро стоїть питання створення ефективного податкового середовища, яке б визначалося не лише розмірами податкового навантаження, а й відповідністю структури обов'язкових платежів та податкового інструментарію рівню розвитку галузі та стану іiі економіки.

Заміна фіксованого сільськогосподарського податку на єдиний податок (четверта) група викликала неоднозначну реакцію науковців i практиків. Маючи багато недоліків теоретичного плану, таких як невідповідність системному підходу до побудови податкової системи, 
неузгодженість бази оподаткування, фіксований сільськогосподарський податок мав й переваги, 3 точки зору практики, оскільки його застосування давало можливість аграріям в кризовий період зберегти i наростити обсяги виробництва та реалізації сільськогосподарської продукції, що забезпечило продовольчу безпеку країни.

Визнання податкового стимулювання як об'єкта державного регулювання дає можливість реалізувати сукупність методів, засобів, важелів державного впливу не тільки на обсяги виробництва, але й на ресурсний потенціал, що відповідає новітній методології управління складними об'єктами. Для досягнення високих результатів державного впливу на розвиток аграрного сектору доцільно виокремити чотири стадіï, на кожній 3 яких має застосовуватися різний інструментарій регулювання: модернізації; ініціалізації експорт орієнтованого зростання; стимулювання прискореного розвитку; розвинутого ринку. На цій підставі сформована принципова схема взаємодії ринкового механізму i механізму державного регулювання розвитку аграрного сектору економіки залежно від цих стадій (рис. 1).

Основною метою податкового стимулювання суб'єктів господарювання аграрної галузі є економічний вплив держави на виробництво, переробку i реалізацію сільськогосподарської продукції, сировини і продовольства, а також матеріально-технічне забезпечення, спрямоване на підвищення ефективності діяльності на всіх рівнях i погодження інтересів держави i підприємств. Пріоритетними напрямами при податковому стимулюванні аграріїв $\epsilon$ забезпечення продовольчої безпеки, зниження податкового тягаря, здатних стабілізувати виробництво та реалізацію сільськогосподарської продукції.

\section{Податкове стимулювання аграрної галузі}

Мета. Економічний вплив держави на виробництво, переробку i реалізацію сільськогосподарської продукції, сировини і продовольства, а також матеріально-технічне забезпечення, спрямоване на підвищення ефективності діяльності на всіх рівнях і погодження інтересів держави і підприємств

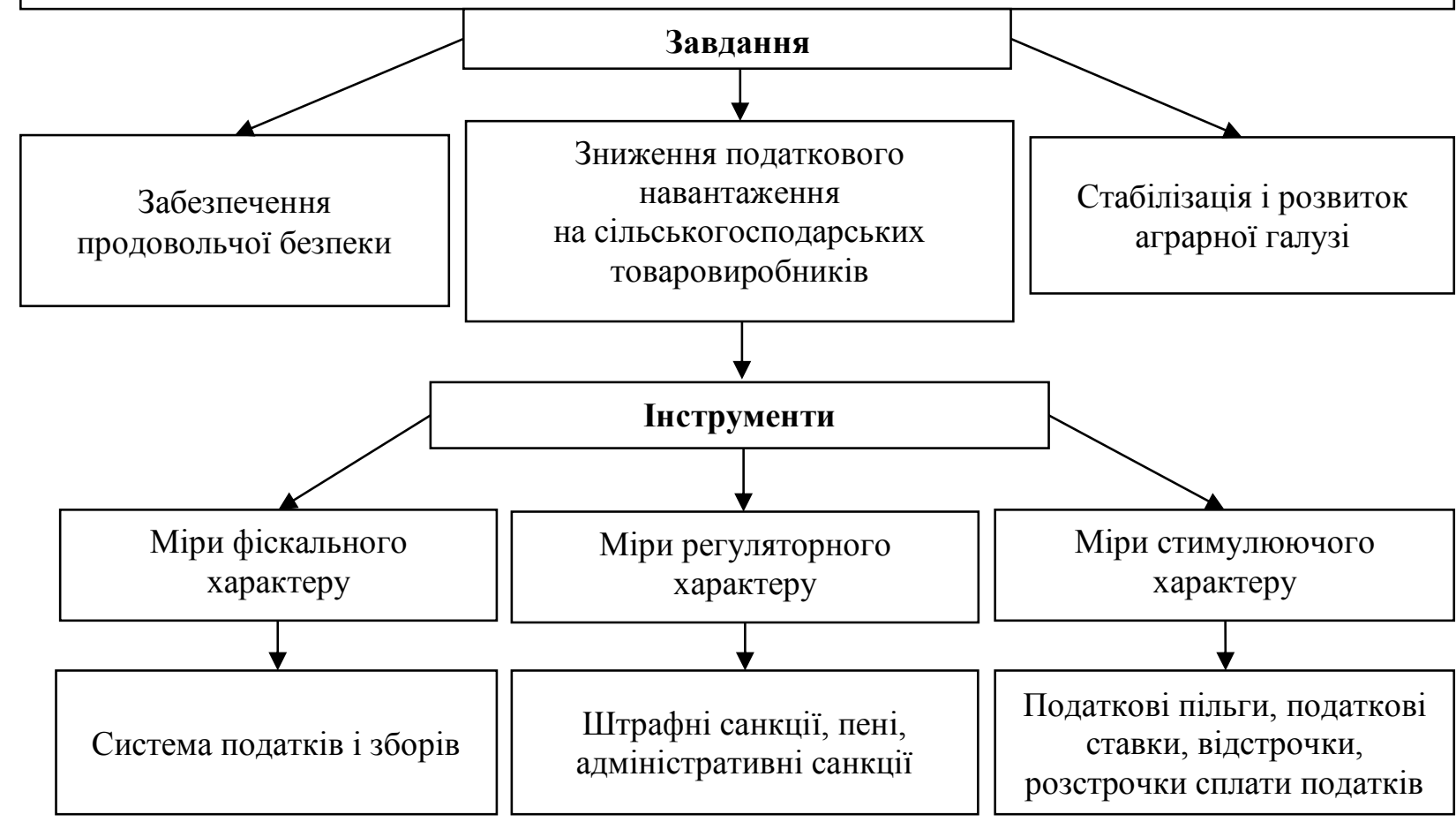

Рис. 1. Система податкового стимулювання суб'єктів господарювання аграрної галузі

В основі податкового стимулювання повинні бути задіяними всі функції податкової системи такі як стимулююча, фіскальна та регуляторна, які спрямовані на зменшення податкового тягаря 
на суб'єктів господарювання аграрної галузі через систему податків і зборів, штрафні санкції, податкові пільги, розстрочення податкових зобов'язань, податкові ставки тощо.

Політика податкового стимулювання реалізується переважно через застосування податкових пільг. Податкові пільги можна класифікувати за критеріями:

- терміну дії (постійні, тимчасові);

- спрямованості (стимулюючі, винагороджувальні);

- рівня запровадження (загальнодержавні, регіональні);

- сферою дії (для окремих платників, для окремих видів діяльності, змішані);

- механізмом встановлення (вилучення зі складу платників податку, вилучення 3 об'єкта оподаткування, зменшення бази оподаткування, зниження ставок оподаткування, зменшення нарахованого податкового зобов'язання, подовження строків сплати податкового зобов' язання, звільнення від сплати податкового зобов'язання). Обов'язковою умовою реалізації стимулюючого потенціалу податкових важелів регулювання економічного розвитку $\epsilon$ формування нових підходів до надання пільг і преференцій суб'єктам господарювання та удосконалення самого механізму податкового стимулювання (Albu, 2019).

Реформування податкової системи має здійснюватися відповідно до пріоритетів державної політики соціально-економічного розвитку, сприяти сталому економічному зростанню шляхом лібералізації податкової системи на основі збалансованої політики, забезпечення достатньої суми загальних податкових надходжень до бюджетів усіх рівнів та встановити ліберальне ставлення до платників, які сумлінно виконують податкові зобов'язання, та посилити відповідальність за ухилення від сплати податків (Dolzhenko, 2016).

Проведене дослідження свідчить, що на даному етапі фінансово економічного розвитку податкове регулювання суб'єктів господарювання аграрної галузі не повною мірою сприяє розвитку та росту виробництва, функціонування їх на самофінансуванні і самоокупності. Зокрема, враховуючи i високі показники податкового навантаження на сільськогосподарські товаровиробники 3 відміною спеціального режиму оподаткування податком на додану вартість та збільшенням ставок і бази оподаткування єдиним податком (четверта) група можна констатувати, що фінансовий стан сільськогосподарських підприємств не дозволяє в більшості випадків їм авансувати фінансові ресурси на розширене відтворення, займатися інвестиційною діяльністю, оскільки після виконання всіх податкових зобов'язань у розпорядженні підприємств залишається незначна сума прибутку. Вирішення цієї проблеми можливе шляхом дієвості комплексу заходів 3 розвитку податкового стимулювання (табл. 2).

Серед низки заходів слід виокремити:

- зміцнення нормативно-правової бази оподаткування;

- підвищення податкової грамотності господарюючих суб'єктів галузі;

- удосконалення i адаптація заходів державної підтримки суб'єктів агробізнесу;

- активізація інноваційної діяльності в галузі;

- розвиток інвестиційного податкового кредитування;

- надання додаткових податкових пільг;

- врахування впливу сезонності

сільгоспвиробництва при оподаткуванні.

Такий комплекс заходів сприятиме:

- підвищенню інноваційної активності сільськогосподарських товаровиробників;

- нарощуванню обсягів виробництва та реалізації продукції;

- зростанню чистого прибутку

підвищенню економічної ефективності;

- оздоровленню фінансово-економічної діяльності підприємств;

- стимулюванню інвестиційної привабливості;

- залученню іноземних інвестицій;

- збільшенню стягнень податків за рахунок виведення «з тіні» діючого агробізнесу.

Найважливішими завданнями, які вирішуються за допомогою податкового регулювання на макрорівні, є такі:

- регулювання попиту та пропозиції (вирішення цієї проблеми забезпечується шляхом зміни взаємозв'язку між прямими та непрямими податками, обмеження попиту на певні групи товарів через запровадження спеціальних податків, у тому числі акцизних зборів);

- формування раціональних відносин між накопиченням і споживанням; Зменшення податкового навантаження зазвичай призводить до більш швидкого збільшення заощаджень; 
Таблиия 2. Комплекс заходів з розвитку податкового стимулювання через діяльності суб'сктів господарювання аграрної галузі

\begin{tabular}{|c|c|c|c|}
\hline $\begin{array}{c}\text { Наявний потенціал } \\
\text { для розвитку } \\
\text { аграрної галузі }\end{array}$ & $\begin{array}{c}\text { Напрями } \\
\text { вдосконалення } \\
\text { податкового } \\
\text { стимулювання }\end{array}$ & $\begin{array}{c}\text { Механізми, } \\
\text { що сприяють } \\
\text { втіленню заходів } \\
\text { з податкового } \\
\text { стимулювання }\end{array}$ & $\begin{array}{c}\text { Ефект від реалізації } \\
\text { заходів податкового } \\
\text { стимулювання }\end{array}$ \\
\hline 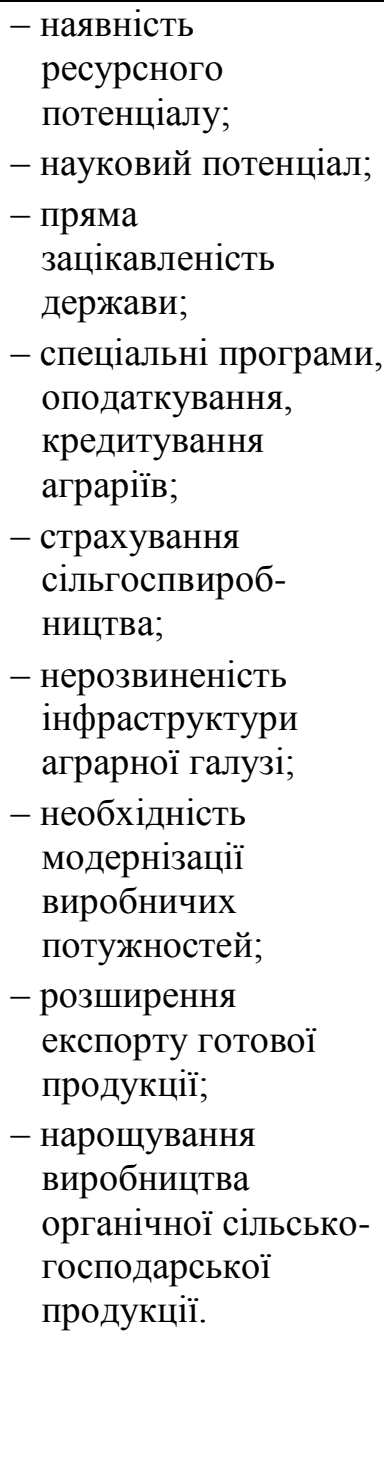 & $\begin{array}{l}\text { - зміцнення } \\
\text { нормативно- } \\
\text { правової бази } \\
\text { оподаткування; } \\
\text { - підвищення } \\
\text { податкової } \\
\text { грамотності } \\
\text { господарюючих } \\
\text { суб'єктів галузі; } \\
\text { - удосконалення і } \\
\text { адаптація заходів } \\
\text { державної } \\
\text { підтримки } \\
\text { суб'єктів } \\
\text { агробізнесу; } \\
\text { - активізація } \\
\text { інноваційної } \\
\text { діяльності в галузі; } \\
\text { - розвиток } \\
\text { інвестиційного } \\
\text { податкового } \\
\text { кредитування; } \\
\text { - надання } \\
\text { додаткових } \\
\text { податкових пільг; } \\
\text { - врахування впливу } \\
\text { сезонності } \\
\text { сільгоспвироб- } \\
\text { ництва при } \\
\text { оподаткуванні. }\end{array}$ & $\begin{array}{l}\text { - інвестиційний } \\
\text { податковий кредит; } \\
\text { - податковий кредит; } \\
\text { - податкові канікули; } \\
\text { - зниження розмірів } \\
\text { страхових внесків; } \\
\text { - фіксована база і } \\
\text { ставки єдиного } \\
\text { податку (четверта) } \\
\text { група; } \\
\text { - надання } \\
\text { державних } \\
\text { гарантій захисту } \\
\text { від різкого } \\
\text { зростання } \\
\text { податкового тягаря } \\
\text { на термін } \\
\text { до } 5 \text { років. }\end{array}$ & $\begin{array}{l}\text { - підвищення інноваційної } \\
\text { активності підприємств } \\
\text { галузі; } \\
\text { - нарощування обсягів } \\
\text { виробництва та реалізації } \\
\text { продукції; } \\
\text { - зростання чистого } \\
\text { прибутку та підвищення } \\
\text { економічної ефективності; } \\
\text { - оздоровлення } \\
\text { фінансово- економічної } \\
\text { діяльності підприємств; } \\
\text { - диверсифікація } \\
\text { виробництва; } \\
\text { - стимулювання } \\
\text { інвестиційної } \\
\text { привабливості; } \\
\text { - залучення в агробізнес } \\
\text { нових суб'єктів } \\
\text { господарювання; } \\
\text { - залучення іноземних } \\
\text { інвестицій; } \\
\text { - збільшення стягнень } \\
\text { податків за рахунок } \\
\text { виведення «з тіні» діючого } \\
\text { агробізнесу; } \\
\text { - розвиток інфраструктури } \\
\text { та сільських територій } \\
\text { за рахунок державного } \\
\text { фінансування; } \\
\text { - поліпшення умов праці } \\
\text { працівників галузі. }\end{array}$ \\
\hline
\end{tabular}

- вплив на темпи інфляційних процесів. 3 одного боку, податки розглядаються як засіб захоплення надлишкової грошової маси, а 3 іншого боку, зміни ставок непрямих податків впливають на рівень цін. Високі податки супроводжуються подвійний інфляцією: а) через зменшення (переходу в тінь) бази та збільшення дефіциту бюджету;

- через бажання підприємців компенсувати податкові пільги додатковим доходом від зростання цін. У той же час, збільшення податкового навантаження на доходи громадян стримує платоспроможний попит і певною мірою може протидіяти зростанню цін 3 боку виробників.

\section{Висновки}

Як результат, ми вважаємо, що держава 
P. Bechko, S. Kolotukha, S. Ptashnyk, Ju. Nahorna

повинна гарантувати стабільність основних податкових принципів, а механізми та правила їх функціонування повинні бути записані в документі - Податковому кодексі України. Цей документ повинен відображати суть нової або оновленої податкової політики, не лише визначати шляхи податкових відносин та податкового законодавства, а й поєднувати тенденції та напрямки податкової реформи із стратегією економічного розвитку країни.

\section{References}

Albu, O. B. \& Flyverbom, M. (2019). Organizational transparency: conceptualizations, conditions, and consequence. Business \& Society, 58 (2), 268-297.

doi: https://doi.org/10.1177/0007650316659851.

Alexander, A., De Vito, A. \& Jacob, M. (2020). Corporate tax reforms and tax-motivated profit shifting: evidence from the EU. Accounting and Business Research, 50 (4), 309-341. doi: https://doi.org/10.1080/00014788.2020.1712649.

Christensen, L. T. \& Cornelissen, J. (2015). Organizational transparency as myth and metaphor. European Journal of Social Theory, 18 (2), 132-149. doi: https://doi.org/10.1177/1368431014555256.

Dema, D. I. (2016). Podatkove stymuliuvannia vyrobnytstva ekolohichno chystoi silskohospodarskoi produktsii [Tax Incentives for Production of Ecologically Clean Agricultural Products]. Orhanichne vyrobnytstvo $i$ prodovolcha bezpeka, IV Mizhnarodna naukovo-praktychna konferentsiia (pp. 379-382). Zhytomyr : O. O. Yeveniuk [in Ukrainian].

Dolzhenko, I. I. (2016). Tendentsii biudzhetnopodatkovoho stymuliuvannia silskoho hospodarstva $\mathrm{v}$ Ukraini [Trends in Budgetary and Tax Incentives for Agriculture of Ukraine]. Naukovyi visnyk NUBiP Ukrainy. Ser. Ekonomika, ahrarnyi menedzhment, biznes, 247, 99-110 [in Ukrainian].

Hansen, H. K. \& Flyverbom, M. (2015). The politics of transparency and the calibration of knowledge in the digital age. Organization, 22 (6), 872-889.

doi: https://doi.org/10.1177/1350508414522315.

Hudz, O. Ye. (2012). Podatkove rehuliuvannia rozvytku ahrosfery v Ukraini [Tax Regulation of the Agri-Sphere Development in Ukraine]. Efektyvna ekonomika, 1 . Retrieved from http://www.economy.nayka.com.ua/?op=1\&z=880 [in Ukrainian].

Karlin, M. I. \& Lipovska-Makovetska, N. I.
(2016). Podatkovi systemy krain Azii [Tax systems of Asian countries]. Lutsk : Vezha-Druk [in Ukrainian].

Kotenko, V. (2019). Biznes pohirshyv otsinku podatkovoi systemy Ukrainy [Business has worsened the assessment of Ukraine's tax system]. Retrieved from

https://www.unian.ua/economics/finance/10769573biznes-pogirshiv-ocinku-podatkovoji-sistemiukrajini-yeba.html [in Ukrainian].

Kovalenko, L. O. \& Mikheienko, T. V. (2016). Administruvannia PDV $\mathrm{v}$ systemi finansovoho menedzhmentu [VAT Management in the System of Financial Management]. Naukovyi visnyk Polissia, 4 (8), 293-302 [in Ukrainian].

Kravchuk, O. \& Odosii, O. (2015). Ahrobiznes: dotuvaty chy opodatkovuvaty? [Agribusiness: Subsidize or Impose Taxes?] Retrieved from https://commons.com.ua/uk/podatkova-sistemaagrobiznesu-dotuvati-chi-opodatkovuvati/ Ukrainian].

Krylova, A. O. (2008). Valova dodana vartist yak indykator porivniannia finansovykh system [Gross Value Added as a Comparison Indicator of Financial Systems]. Rehionalna ekonomika, 3, 90-95 [in Ukrainian].

Melnik, A. M. (2016). Improving the Inheritance Taxation as an Element of Real Estate Taxation: the UK Experience. Independent Auditor, 16, 69.

Oats, L. \& Tuck, P. (2019). Corporate tax avoidance: is tax transparency the solution? Accounting and Business Research, 49 (5), 565-583. doi:

https://doi.org/10.1080/00014788.2019.1611726.

Podatkovyi kodeks Ukrainy [Tax Code of Ukraine]. No. 2755 (2010). [in Ukrainian].

Pro vnesennia zmin do Podatkovoho kodeksu Ukrainy ta deiakykh zakonodavchykh aktiv Ukrainy shchodo podatkovoi reformy [On amendments to the Tax Code of Ukraine and some legislative acts of Ukraine on tax reform]. No. 71-VIII. (2014). [in Ukrainian].

Savenko, S. V. (2019). V Ukraini vdvichi pokrashchyvsia reitynh podatkovoho klimatu [Rankings of the Tax Climate in Ukraine has Doubled]. Finance $U A$. Retrieved from https://news.finance.ua/ua/news/-/415318/vukrayini-vdvichi-pokrashhyvsya-rejtyngpodatkovogo-klimatu [in Ukrainian].

Tretiak, A. M. \& Druhak, V. M. (2003). Naukovi osnovy ekonomiky zemlekorystuvannia ta zemlevporiadkuvannia. Kyiv: TSZRU [in Ukrainian]. 